\title{
Characterization of Biochar Derived from Crop Residues for Soil Amendment, Carbon Sequestration and Energy Use
}

\author{
Govindarajan Venkatesh ${ }^{1, *}$, Kodigal A. Gopinath ${ }^{1}$, Kotha Sammi Reddy ${ }^{1}$, Baddigam Sanjeeva Reddy ${ }^{1}$, \\ Mathyam Prabhakar ${ }^{1}$, Cherukumalli Srinivasarao ${ }^{2} \mathbb{D}$, Venugopalan Visha Kumari ${ }^{1}$ and Vinod Kumar Singh $^{1}$ \\ 1 ICAR—Central Research Institute for Dryland Agriculture (CRIDA), Hyderabad 500 059, India; \\ ka.gopinath@icar.gov.in (K.A.G.); k.sammireddy@icar.gov.in (K.S.R.); bs.reddy@icar.gov.in (B.S.R.); \\ m.prabhakar@icar.gov.in (M.P.); v.visha@icar.gov.in (V.V.K.); director.crida@icar.gov.in (V.K.S.) \\ 2 ICAR—National Academy of Agricultural Research Management (NAARM), Hyderabad 500 030, India; \\ cherukumalli2011@gmail.com \\ * Correspondence: g.venkatesh1@icar.gov.in
}

Citation: Venkatesh, G.; Gopinath, K.A.; Reddy, K.S.; Reddy, B.S.;

Prabhakar, M.; Srinivasarao, C.; Visha Kumari, V.; Singh, V.K.

Characterization of Biochar Derived from Crop Residues for Soil Amendment, Carbon Sequestration and Energy Use. Sustainability 2022, 14, 2295. https://doi.org/10.3390/ su14042295

Academic Editors: Simeng Li and Ana Méndez

Received: 10 January 2022

Accepted: 11 February 2022

Published: 17 February 2022

Publisher's Note: MDPI stays neutral with regard to jurisdictional claims in published maps and institutional affiliations.

Copyright: (C) 2022 by the authors. Licensee MDPI, Basel, Switzerland. This article is an open access article distributed under the terms and conditions of the Creative Commons Attribution (CC BY) license (https:// creativecommons.org/licenses/by/ $4.0 /)$.

\begin{abstract}
The crop residues generated in agricultural fields are mostly considered a burden due to their disposal issues. This study attempts to effectively use pigeon pea stalk (PPS) for biochar production, a promising source as a soil amendment for carbon sequestration and alternative fuel source. PPS was pyrolyzed at different loads and reaction times to optimize the kiln temperature (350-400 ${ }^{\circ} \mathrm{C}$ and $450-500{ }^{\circ} \mathrm{C}$ ) and changes in physicochemical properties, higher heating value (HHV) and yield were assessed. The results indicated that biochar yield, volatile matter, bulk density, O/C and $\mathrm{H} / \mathrm{C}$ atomic ratios decreased, whereas fixed carbon, ash content and total porosity increased with increasing kiln temperature across all loads. Biochar produced at $450-500{ }^{\circ} \mathrm{C}\left(18 \mathrm{~kg}\right.$ load kiln $\left.{ }^{-1}\right)$ had higher total carbon, nitrogen, phosphorous, recovered total carbon and total nitrogen, total potential carbon and $\mathrm{CO}_{2}$ reduction potential. Biochar produced at $350-400{ }^{\circ} \mathrm{C}$ had the maximum cation exchange capability $\left(43.0 \mathrm{cmol} \mathrm{kg}{ }^{-1}\right)$. Biochar has estimated $\mathrm{O} / \mathrm{C}$ and $\mathrm{H} / \mathrm{C}$ atomic ratios of $0.07-0.15$ and $0.35-0.50$, respectively. Biochar exhibited good agronomic characteristics and fulfilled key quality criteria of $\mathrm{H} / \mathrm{C}<0.7$ and $\mathrm{O} / \mathrm{C}<0.4$ for soil carbon sequestration, as described by the European Biochar Certificate and the International Biochar Initiative. The estimated mean residence time and the mass fraction of carbon that would remain after 100 years were consistently greater than 1000 years and $80 \%$, respectively. The biochar produced at $450-500{ }^{\circ} \mathrm{C}$ (at $18.0 \mathrm{~kg} \mathrm{kiln}^{-1}$ ) from PPS had higher fixed carbon (65.3\%), energy density (1.51), energetic retention efficiency (53\%), fuel ratio (4.88), and HHV (25.01 MJ kg-1), as well as lower $\mathrm{H} / \mathrm{C}$ and $\mathrm{O} / \mathrm{C}$ ratios, implying that it is suitable for use as an alternative solid fuel.
\end{abstract}

Keywords: pigeon pea stalk biochar; $\mathrm{O} / \mathrm{C}$ and $\mathrm{H} / \mathrm{C}$ atomic ratio; $\mathrm{CO}_{2}$ reduction potential; mean residence time; higher heating value

\section{Introduction}

Biochar is a versatile, low-cost carbonaceous solid product that results from thermal degradation (slow pyrolysis) of biomass under low temperature, low-oxic or anoxic conditions [1]. Temperatures used for slow pyrolysis are typically in the range of $300{ }^{\circ} \mathrm{C}$ to $600{ }^{\circ} \mathrm{C}$. In recent years, the production of biochar via slow pyrolysis technology has piqued interest as a means of managing crop residues, and this conversion is a novel way to potentially add value to crop residues, with additional benefits such as reduced bulkiness, ease of milling, storage, handling, and low transportation costs [2] compared to uncarbonized crop residue. The potential worth of biochar for carbon storage, as well as a high energy material, has become the subject of multi-disciplinary areas of science and engineering research.

Biochar can be used as a soil amendment [3] or a solid fuel akin to low-grade coal [4,5] depending on its physicochemical and energetic qualities. There has been extensive research into using carbon rich biochar to improve soil CEC, water holding capacity, aeration, 
microbial ecology and to neutralize the $\mathrm{pH}$ of acidic soils all while increasing the crop yield $[3,6,7]$. In addition to these purported benefits, biochar has been recognized for its lower $\mathrm{H} / \mathrm{C}$ and $\mathrm{O} / \mathrm{C}$ atomic ratios, with enhanced calorific value and energy density [8]. Furthermore, biochar's exceptional stability, allows it to store carbon in the soil biosphere for 100 to 1000 years, potentially reducing global warming [9,10]. Forest residues [11], agricultural residues [12,13], and agro-industrial waste [14,15] are only a few examples of organic materials that can be pyrolyzed into biochar. Annually, $511 \mathrm{Mt}$ of crop residues is produced in India [16], of which $141 \mathrm{Mt}$ is estimated to be surplus crop residue [17]. Of this, about $93 \mathrm{Mt}$ of crop residues is burnt each year [18]. According to the Government of India estimate [19], 18.53 Mt of pigeon pea stalks (PPS) is produced in India each year. Due to its low digestibility and high lignin content, PPS is never used as animal feed and is often discarded. Furthermore, because of logistical challenges and limited demand, only a small portion of these PPS has been used as low-cost solid biomass fuel in villages for cooking and heating, and most of the PPS have been left unattended in farm fields. Furthermore, unattended agricultural residues with low bulk density and slow decomposition disrupt soil preparation and crop establishment and are frequently burned directly in open fields, posing a major hazard to the environment, biodiversity, and human health [20]. Farmers can use slow pyrolysis to turn their enormous quantities of leftover crop residues into biochar. Soil inclusion of crop residual biochar provides a novel prospect for efficient residue usage and an enticing alternative to open field burning [20].

Previous studies have demonstrated that the feedstock and production conditions have a significant influence on biochar yield [9,13,21,22], physicochemical characteristics [23-35]; stability and mean resident time (MRT) $[9,25,36-43]$, total potential carbon (TPC) and $\mathrm{CO}_{2}$ reduction potential [44-46], and energy properties [47-52]. Thus, detailed information about the complete production process and characterization is a key factor in defining the most appropriate application of biochar, for instance, as highly recalcitrant biochar may function as carbon fixation materials, whereas those rich in elemental compositions or those which have high porosity could be used as amendments to improve soil fertility [3] or those with a higher heating value (HHV) could be exploited to produce solid fuel in the form of briquettes [41] for industrial applications.

However, there is limited information available on the impact of production conditions on biochar's compositional quality and energy characteristics made from PPS in India. Hence, experimentation with this kind of crop stalk is of great interest and detailed studies are required to optimize the production conditions and characterization of biochar from PPS. Biochar was made from PPS in this experiment using a biochar kiln developed at ICAR-CRIDA in Hyderabad [30,31]. As a result, the primary objective of this research was to evaluate the physicochemical and energy properties of PPS biochar under various production conditions in order to determine its suitability for usage as a soil amendment and an energy alternative. The specific objectives were, (1) to determine biochar's stability and carbon sequestration potential, and (2) to quantify its energy potential.

\section{Materials and Methods}

\subsection{Feed Stock and Biochar Preparation}

The PPS (Cajanus cajan (L.) Millsp.; a leguminous plant) used in the present study was obtained from Hayathnagar Research Farm, ICAR-Central Research Institute for Dryland Agriculture, Hyderabad, India. The raw materials were dried to a moisture level of less than $9 \%$ before being chopped into $15-19 \mathrm{~cm}$ segments with a diameter of 10-33 mm. To ensure uniformity, the stalk samples were combined and stored in dry conditions. With a $\mathrm{C} / \mathrm{N}$ ratio of 40.7 , the PP stalk had $68.2 \%$ volatile matter, $17.0 \%$ fixed carbon, $14.9 \%$ ash, $460.0 \mathrm{~g} \mathrm{~kg}^{-1}$ total C, $11.3 \mathrm{~g} \mathrm{~kg}^{-1}$ total $\mathrm{N}, 2.9 \mathrm{~g} \mathrm{~kg}^{-1}$ total $\mathrm{P}$, and $3.0 \mathrm{~g} \mathrm{~kg}^{-1}$ total $\mathrm{K}$.

The biochar kiln unit and its operations have been described in detail by Venkatesh et al., [31]. The process of biochar made in this study consisted of subjecting the PPS sample to twenty-four test runs (4 replicates (n); 3 load types- 8, 13 and $18 \mathrm{~kg} \mathrm{kiln}^{-1}$; two reaction times for each load type; degrees of freedom >12) in a CRIDA biochar kiln 
unit with limited air supply. Reaction time is the amount of time taken for the PPS to achieve the necessary thermal conditions for the development of separate end stages (grey and blue colour phases), as well as for approximating kiln temperature. Using a digital clock, the target end stage for each load type was recorded. In this study, we looked at the effect of PPS quantity on reaction time. Two varying reaction times were recorded for the development of end stage in each load group. Blue colour had a longer reaction time than grey colour, which corresponded to a higher kiln temperature. Based on the earlier studies [30,31,53], kiln temperatures of about $350-400{ }^{\circ} \mathrm{C}$ and $450-500{ }^{\circ} \mathrm{C}$ were ascribed to grey and blue colour phase, respectively, in the text to facilitate inference (Table 1 ). The temperature ranges of $350-400{ }^{\circ} \mathrm{C}$ and $450-500{ }^{\circ} \mathrm{C}$ adopted in this study are indicative of typical ranges for slow pyrolysis for higher biochar yield [54]. After cooling by convection and radiation, the biochar was placed in airtight plastic containers until further analyses. Biochar produced in each run were weighed on a mass basis using an electrical balance of having the least count of $0.001 \mathrm{~g}$. Biochar yield $\left(\mathrm{Y}_{\text {biochar }}\right)$ was calculated as the proportion of the mass of pyrolysis product to the raw stalk as follows:

Table 1. Colour phase correlation with temperature range for different PPS load and reaction time during conversion process.

\begin{tabular}{cccc}
\hline Load (kgkiln $\left.{ }^{-1}\right)$ & Reaction Time (min) & $\begin{array}{c}\text { Color Phase } \\
\text { Development }\end{array}$ & $\begin{array}{c}\text { Corresponding } \\
\text { Temperature Range }\left({ }^{\circ} \mathbf{C}\right)\end{array}$ \\
\hline 8 & 9 & Grey & $350-400$ \\
8 & 10 & Blue & $450-500$ \\
13 & 11 & Grey & $350-400$ \\
13 & 13 & Blue & $450-500$ \\
18 & 15 & Grey & $350-400$ \\
18 & 16 & Blue & $450-500$ \\
\hline
\end{tabular}

$\mathrm{Y}_{\text {biochar,ad }}(\mathrm{wt} \% . \mathrm{ad})=\left(\mathrm{M}_{\text {biochar }} / \mathrm{M}_{\text {stalk }}\right) \times 100$, where $\mathrm{M}_{\text {biochar }}$ was the mass of biochar $(\mathrm{kg})$ and $\mathrm{M}_{\text {stalk }}$ was the total mass of the raw stalk $(\mathrm{kg})$ loaded into the kiln and $Y_{\text {biochar,ad }}$ represents the air-dried yield of biochar (\%) [55].

\subsection{Biochar Characterization}

A representative biochar sample in quadruplicates from each combination of kiln load and temperature range were homogenized, grounded to $\leq 0.21 \mathrm{~mm}$ sieve (70 mesh), and oven dried at $105^{\circ} \mathrm{C}$ for $24 \mathrm{~h}$ prior to characterization using various procedures for determining proximate (volatile matter, ash and fixed carbon content) and ultimate $(\mathrm{pH}$, electrical conductivity, bulk density, total porosity, cation exchange capacity, total carbon, nitrogen, phosphorous and potassium) content

\subsubsection{Proximate Analysis}

Volatile matter (VM) of the PPS and biochar samples were determined according to ASTM D 1762-84 [56] on an oven dry-weight basis by measurement of weight loss/mass balance from a sequential muffle procedure. The percentage of VM was determined based on the loss in weight of test sample after deducting the loss in weight due to moisture, i.e.,

$$
\text { Volatile matter }(\%)=\left(\mathrm{M}_{\text {biochar or stalk }}-\mathrm{M}_{\mathrm{CC}} / \mathrm{M}_{\text {biochar or stalk }}\right) \times 100
$$

where $\mathrm{M}_{\text {biochar or stalk }}$ was the initial dry mass of biochar/stalk, $\mathrm{M}_{\mathrm{CC}}$ was dry mass of the carbonized biochar or stalk that remained after heating.

Ash content of the PPS and biochar samples were determined by dry combustion of the carbonized biochar/stalk residue of the VM determination, according to ASTM D 1762-84 [56], i.e.,

$$
\text { Biochar or Stalk ash }(\%)=\left(\mathrm{M}_{\mathrm{ash}} / \mathrm{M}_{\mathrm{biochar} \mathrm{or} \mathrm{stalk}}\right) \times 100
$$


where $\mathrm{M}_{\text {ash }}$ was the dry mass of ash remains following dry combustion of the carbonized biochar or stalk, $\mathrm{M}_{\text {biochar or stalk }}$ was the initial dry mass of biochar or stalk.

Fixed carbon (FC) in the PPS and biochar was calculated as follows:

Fixed carbon (FC) $(\%)=(100-\% \mathrm{VM}-\%$ Ash $)[55]$.

\subsubsection{Ultimate Analysis}

The $\mathrm{pH}$ of the biochar was determined by soaking $1 \mathrm{~g}$ of biochar in $20 \mathrm{~mL}$ of deionized water $(1: 20 \mathrm{w} / \mathrm{v})$ for $10 \mathrm{~min}$ under agitation and was measured using a $\mathrm{pH}$ meter (Systronics $\mathrm{pH}$ system 362). The electrical conductivity (EC) of the biochar was measured at room temperature in a 1:10 $w / v$ suspension (biochar: deionized water) after $24 \mathrm{~h}$ using an EC meter (Systronics conductivity meter 306).

Bulk density (BD) and total porosity of biochar were determined by using the Hilgard or Keen Rackzowski box method [57]. The cation exchange capacity of biochar was determined at $\mathrm{pH} 7$ after displacement by using the $1 \mathrm{~N}$ ammonium acetate method and then estimated titrimetrically by distillation of ammonium that was displaced by sodium [23]. Total carbon $(\mathrm{C})$ and nitrogen $(\mathrm{N})$ in PPS and biochar were determined directly by dry combustion on a Vario El Cube CHN analyzer (Elementar, Germany). The results of total C and $\mathrm{N}$ analysis were used to calculate the $\mathrm{C} / \mathrm{N}$ ratio. The concentration of total phosphorous ( $\mathrm{P}$ ) and potassium $(\mathrm{K})$ was determined after digesting $0.5 \mathrm{~g}$ each of PPS and biochar sample in a di-acid mixture of nitric $\left(\mathrm{HNO}_{3}\right)$ and perchloric $\left(\mathrm{HClO}_{4}\right)$ acids (3:1 ratio) [58]. The digests were filtered using Whatman No. 42 filter paper. Total $\mathrm{P}$ in the filtrate was analyzed by Vanadomolybdo phosphoric yellow colour method at $420 \mathrm{~nm}$ using a spectrophotometer (Genesys 6, Thermo Fischer Scientific, Waltham, MA, USA). The clear digest was then analyzed for total $\mathrm{K}$ using a flame photometer.

\subsubsection{Recovery of Total Carbon and Nitrogen in Biochar}

Recovery of total carbon $(\mathrm{C})$ and nitrogen $(\mathrm{N})$ in the biochar following slow pyrolysis was determined for each pyrolytic run based on the load $\left(\mathrm{kg} \mathrm{kiln}^{-1}\right)$, biochar yield (\%), total C and N (\%) content of PPS and biochar as follows [59],

Total $\mathrm{C}$ or $\mathrm{N}$ in raw stalk $(\mathrm{g})=\left[\right.$ Raw stalk $\mathrm{kiln}^{-1}(\mathrm{~kg}) \times$ total $\mathrm{C}$ or $\mathrm{N}$ in raw stalk $\left.(\%)\right] / 100$

Biochar yield $(\mathrm{kg})=\left[\right.$ Biochar yield $(\%) \times$ raw stalkkiln $\left.{ }^{-1}(\mathrm{~kg})\right] / 100$

Total C or $\mathrm{N}$ in biochar $(\mathrm{kg})=$ total $\mathrm{C}$ or $\mathrm{N}$ in biochar $(\%) / 100$

Total C or $\mathrm{N}$ loss $(\mathrm{kg})=$ Total C or $\mathrm{N}$ in raw stalk $(\mathrm{kg})-$ total C or $\mathrm{N}$ in biochar $(\mathrm{kg})$

Total C or $\mathrm{N}$ loss $(\%)=[$ Total C or $\mathrm{N}$ loss $(\mathrm{kg}) \times 100] /$ Total C or $\mathrm{N}$ in raw stalk $(\mathrm{kg})$

Total C or N recovery $(\%)=100-$ total C or $\mathrm{N}$ loss $(\%)$

\subsubsection{Biochar Stability}

Based on the proximate analysis data, the $\mathrm{H} / \mathrm{C}$ and $\mathrm{O} / \mathrm{C}$ atomic ratios for the biochar were estimated by using Equations (1) and (2) [39],

$$
\begin{aligned}
& \mathrm{H} / \mathrm{C}=0.397 \times(\mathrm{VM} / \mathrm{FC})+0.251 \\
& \mathrm{O} / \mathrm{C}=0.188 \times(\mathrm{VM} / \mathrm{FC})+0.035
\end{aligned}
$$

where FC is the percentage of fixed carbon content and VM is the percentage of volatile matter content in the biochar.

Mean residence time and the percent of carbon that would remain in the soil after 100 years $\left(\mathrm{BC}_{+100}\right)$ was calculated according to Equations (3) and (4) [37],

$$
\begin{aligned}
\mathrm{MRT} & =4501 \times \mathrm{e}^{-3.2 \times(\mathrm{H} / \mathrm{C})} \\
\mathrm{BC}_{+100} & =1.05-0.616 \times(\mathrm{H} / \mathrm{C})
\end{aligned}
$$


where $\mathrm{MRT}$ andBC +100 are mean residence time (MRT expressed in years) and the \% of carbon that would remain in the soil after 100 years $\left(\mathrm{BC}_{+100}\right)$, respectively. $\mathrm{H} / \mathrm{C}$ stand for the atomic ratio of the biochar. The letter ' $\mathrm{e}$ ' represents the term exponential.

\subsubsection{Carbon Dioxide Reduction Potential}

The total potential carbon (TPC) was calculated according to Equation (5) [46],

TPC in biochar ( $\mathrm{g}$ of $\mathrm{C} \mathrm{kg}^{-1}$ of biochar) = Total biochar yield ( $\mathrm{kg}$ of biochar

$$
\mathrm{kg}^{-1} \text { of stalk) } \times \text { Fixed carbon ( } \mathrm{kg} \text { of FC kg }{ }^{-1} \text { of biochar) }
$$

Finally, the carbon di-oxide reduction potential $\left(\mathrm{CO}_{2} \mathrm{eq} \mathrm{kg}{ }^{-1}\right.$ of biochar) was estimated according to Equation (6) [44],

$\mathrm{CO}_{2}$ reduction potential $=\mathrm{TPC}$ in biochar $\left(\mathrm{g}\right.$ of $\mathrm{C} \mathrm{kg}^{-1}$ of biochar $) \times(80 / 100)$

$$
\times(44 / 12)
$$

\subsubsection{Fuel Properties}

Based on the result of the proximate analysis, the elemental composition of common organic elements such as hydrogen $(\mathrm{H})$, and oxygen $(\mathrm{O})$ for the PPS were estimated using empirical correlation Equations (7) and (8) developed by Parik et al., [52],

$$
\begin{aligned}
& \mathrm{H}(\%)=0.052 \times \mathrm{FC}+0.062 \times \mathrm{VM} \\
& \mathrm{O}(\%)=0.304 \times \mathrm{FC}+0.476 \times \mathrm{VM}
\end{aligned}
$$

where $\mathrm{FC}$ is the percentage of fixed carbon content and VM is the percentage of volatile matter content in the PPS.

The calorific or higher heating value (HHV) of samples of the PPS and biochar was calculated using the correlation expressed in Equation (9).

$$
\mathrm{HHV}\left(\mathrm{MJ} \mathrm{kg}^{-1}\right)=0.3536 \times \mathrm{FC}+0.1559 \times \mathrm{VM}-0.0078 \times \text { Ash }
$$

where FC is the percentage of fixed carbon content, VM is the percentage of volatile matter content and Ash is the percentage of ash content in the PPS and biochar, respectively [52].

The data of product yield and proximate analysis associated with the biochar were used to calculate energy densification $\left(E_{d}\right)$, energetic retention efficiency (ERE), HHV improvement $\left(\mathrm{HHV}_{\mathrm{i}}\right), \mathrm{FC}$ densification $\left(\mathrm{FC}_{\mathrm{d}}\right), \mathrm{FC}$ recovery efficiency $\left(\mathrm{FC}_{\mathrm{re}}\right)$ and fuel ratio (Fr) of biochar according to Equations (10)-(15) [48,51],

$$
\begin{gathered}
\text { Energy densification }\left(\mathrm{E}_{\mathrm{d}}\right)=\text { HHV of dried biochar } / \mathrm{HHV} \text { of dried PPS } \\
\text { Energy retention efficiency (ERE) }(\%)=\mathrm{E}_{\mathrm{d}} \times \text { biochar yield } \\
\text { HHV improvement }\left(\mathrm{HHV}_{\mathrm{i}}\right)=(\mathrm{HHV} \text { of dried biochar }-\mathrm{HHV} \text { of dried } \\
\qquad \mathrm{PPS}) / \mathrm{HHV} \text { of dried PPS }
\end{gathered}
$$

Fixed carbon densification $\left(\mathrm{FC}_{\mathrm{d}}\right)=\mathrm{FC}$ of dried biochar $/ \mathrm{FC}$ of dried PPS

Fixed carbon recovery efficiency $\left(\mathrm{FC}_{\mathrm{re}}\right)(\%)=\mathrm{FC}_{\mathrm{d}} \times$ Biochar yield

Fuel ratio $(\mathrm{Fr})=$ Fixed carbon of biochar/Volatile matter of biochar

\subsubsection{Statistical Analyses}

Results were expressed as means of the four replicates $(\mathrm{n}) \pm$ standard deviation. Data (treatments 06; replications 04; degrees of freedom >12) were statistically analysed using SAS Version 9.2 (SAS Institute Inc., Cary, NC, USA) with ANOVA. To elucidate significant differences between means $(p<0.05)$, post hoc comparisons were made using Tukey's HSD. 


\section{Results and Discussion}

\subsection{Biochar Yield}

The pyrolysis parameters, such as temperature and reaction time, have a significant impact on biochar output [60]. According to the findings, the yield of biochar from PPS decreased significantly when the kiln temperature increased from $350-400{ }^{\circ} \mathrm{C}$ to $450-500{ }^{\circ} \mathrm{C}$ among three loads of PPS (Table 2). The biochar yield significantly varied from 36.1 to $13.5 \%$ (DW basis). The lowest biochar mass yield (13.5\%) was observed at the temperature of $450-500{ }^{\circ} \mathrm{C}\left(13.0 \mathrm{~kg}\right.$ load $\mathrm{kiln}^{-1}$; reaction time of $\left.13.0 \mathrm{~min}\right)$. The yield reduction with increase in temperature may be due to complete decomposition of hemicellulose at 220-315 ${ }^{\circ} \mathrm{C}$ and cellulose at $315-400{ }^{\circ} \mathrm{C}$ [33] compared to incomplete and slow thermal degradation of lignin at $500{ }^{\circ} \mathrm{C}$ [22]. We observed significantly higher biochar yield at the lower temperature range $\left(350-400{ }^{\circ} \mathrm{C}\right)$, due to negligible condensation and volatilization of organic substances in the feedstock [21].

Table 2. Effect of process parameters on yield, ash, volatile matter and fixed carbon of biochar produced from PPS.

\begin{tabular}{|c|c|c|c|c|c|c|}
\hline $\begin{array}{c}\text { Load } \\
\left(\text { kgkiln }^{-1}\right)\end{array}$ & $\begin{array}{l}\text { Reaction Time } \\
\text { (min) }\end{array}$ & $\begin{array}{c}\text { Temp. Range } \\
\left({ }^{\circ} \mathrm{C}\right)\end{array}$ & $\begin{array}{c}\text { Biochar Yield }^{1} \\
(\%)\end{array}$ & $\operatorname{Ash}^{2}(\%)$ & $\mathrm{VM}^{2}(\%)$ & $\mathrm{FC}^{2}(\%)$ \\
\hline 8 & 9 & $350-400$ & $21.3 \pm 1.0^{b}$ & $32.9 \pm 0.9^{b}$ & $26.0 \pm 2.0^{a}$ & $41.1 \pm 0.9^{\mathrm{d}}$ \\
\hline 8 & 10 & $450-500$ & $18.5 \pm 0.3^{c}$ & $40.1 \pm 0.9^{\mathrm{a}}$ & $16.7 \pm 0.5^{b}$ & $43.1 \pm 0.6^{\mathrm{d}}$ \\
\hline 13 & 11 & $350-400$ & $21.6 \pm 1.0^{\mathrm{b}}$ & $40.4 \pm 0.4^{\mathrm{a}}$ & $15.8 \pm 0.4^{b}$ & $43.8 \pm 0.7^{\mathrm{d}}$ \\
\hline 13 & 13 & $450-500$ & $13.5 \pm 0.3^{d}$ & $41.7 \pm 0.5^{\mathrm{a}}$ & $11.8 \pm 0.5^{c}$ & $46.7 \pm 1.0^{\mathrm{c}}$ \\
\hline 18 & 15 & $350-400$ & $36.1 \pm 0.8^{\mathrm{a}}$ & $31.2 \pm 0.7^{b}$ & $16.9 \pm 0.9^{b}$ & $51.9 \pm 0.7^{b}$ \\
\hline 18 & 16 & $450-500$ & $35.0 \pm 0.6^{\mathrm{a}}$ & $21.3 \pm 1.0^{\mathrm{c}}$ & $13.4 \pm 0.9^{c}$ & $65.3 \pm 3.0^{a}$ \\
\hline
\end{tabular}

Value is the mean \pm standard deviation; Mean values followed by different letters within the same column are significantly different $\left(p<0.05 ; n=4\right.$; ANOVA; Tukey's HSD test); ${ }^{1}$ Biochar yield expressed on air-dried weight basis; ${ }^{2}$ Ash, volatile matter (VM) and fixed carbon (FC) content were expressed on dry weight basis.

\subsection{Proximate Analysis}

Variations in results for fixed carbon, ash and volatile matter contents of the biochar (Table 2) obtained with increasing temperature were in accordance with general trends reported [29,55]. Fixed carbon and ash contents of biochar increased significantly from 41.1 to $65.3 \%$ and 21.3 to $41.7 \%$ per unit dry weight in all loads as the temperature increased from $350-400{ }^{\circ} \mathrm{C}$ to $450-500{ }^{\circ} \mathrm{C}$, whereas VM content decreased significantly from 26.0 to $11.8 \%$ per unit dry weight as the temperature increased in each load. PPS pyrolyzed at $450-500{ }^{\circ} \mathrm{C}$ (at $18 \mathrm{~kg}$ load kiln ${ }^{-1}$ ) had the highest fixed carbon content (65.3\% per unit dry weight), owing to the presence of higher carbon content in the PPS $\left(460 \mathrm{~g} \mathrm{~kg}^{-1}\right)$. When pyrolyzed at $450-500{ }^{\circ} \mathrm{C}$ (at $13 \mathrm{~kg}$ load kiln ${ }^{-1}$ ), biochar had significantly higher ash content $(41.7 \%$ per unit dry weight). Enders et al., [25] observed that during biomass pyrolysis, interactions between organic and inorganic elements may favour high ash content in biochar. We also noticed a reduction in volatile matter content in the biochar with an increase in the temperature. With an increase in carbonization temperature from $350-400{ }^{\circ} \mathrm{C}$ to $450-500{ }^{\circ} \mathrm{C}$, the maximum reduction in volatiles $(36.0 \%)$ was observed in biochar produced at $8 \mathrm{~kg}$ load kiln ${ }^{-1}$ while the lowest was (20.7\%) in biochar produced from $18 \mathrm{~kg}$ load kiln ${ }^{-1}$. This finding showed that the higher the temperature, the higher will be the biochar stability [31]. Regardless of the ash contents, the VM/FC ratio decreased significantly to 0.21 with an increase in kiln temperature indicating its resistance to further decomposition, biological as well as thermal [54].

\subsection{Ultimate Analysis}

\subsubsection{Bulk Density and Total Porosity}

The purpose of carbonization through slow pyrolysis was to enrich the carbon content and to create a porous and less dense biochar from PPS. The total porosity and bulk density values of PPS biochar indicate that the resultant physical structure had changed 
after carbonization. There was a decrease in bulk density and an increase in total porosity of biochar across all loads with the increase in the kiln temperature from $350-400{ }^{\circ} \mathrm{C}$ to $450-500{ }^{\circ} \mathrm{C}$ (Figure 1). Bulk density of biochar dropped significantly from 0.34 to $0.28 \mathrm{Mg}$ $\mathrm{m}^{-3}$, while the corresponding total porosity values of the biochar significantly increased from 49.1 to $108.5 \%$ (at 8,13 and $18 \mathrm{~kg}$ load $\mathrm{kiln}^{-1}$ ), respectively. The drop in bulk density of biochar may be attributed to the organic matter decomposition leading to the transformation of biomass matrices into a lighter and porous structure [34]. Increased pyrolysis temperature results in dramatic rise in porosity [9] due to increases in dehydroxylation of water molecules, thereby resulting in the formation of pores on the surface of biochar [35]. Lower bulk density of $0.28 \mathrm{Mg} \mathrm{m}^{-3}$ was related to maximum total porosity of $108.5 \%$ for the biochar with $18 \mathrm{~kg}$ load $\mathrm{kiln}^{-1}$ at $450-500{ }^{\circ} \mathrm{C}$. Higher pyrolysis temperatures lead to the formation of low density biochar with high internal porosity [34]. Soil application of low bulk density biochar with high total porosity is particularly helpful in improving soil aeration, water holding capacity, nutrient retention, harbouring of micro-organisms, increasing the fertiliser use efficiency of soil, soil workability and plant growth $[2,61]$.
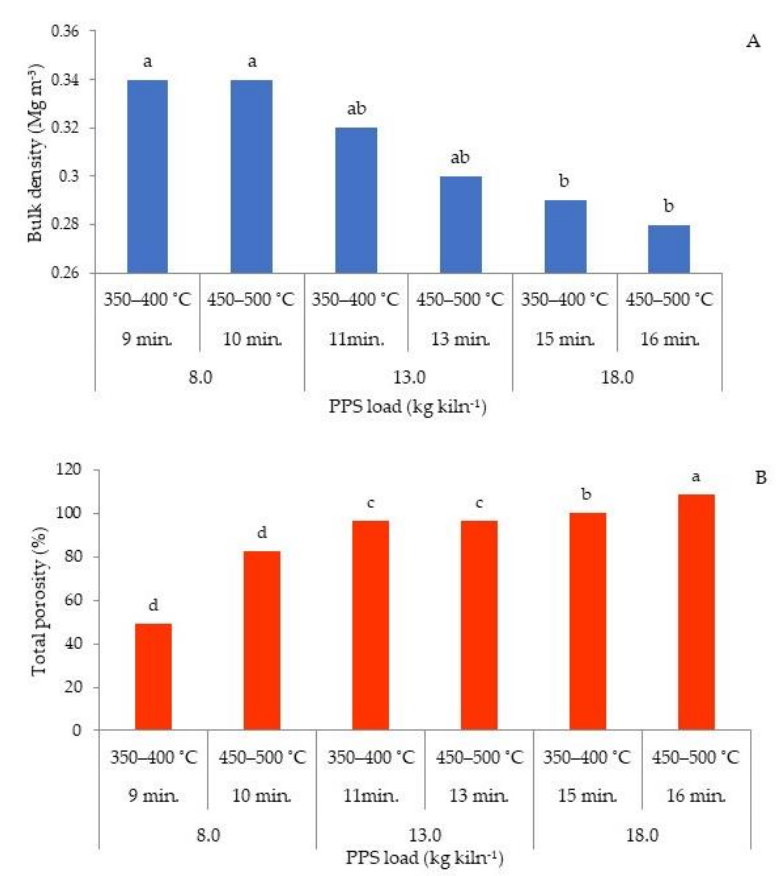

Figure 1. Bulk density (A) and total porosity (B) of biochar produced from PPS. Different letters above bars indicate significant differences ( $p<0.05 ; n=4$; ANOVA; Tukey's HSD test).

\subsection{2. $\mathrm{pH}$ and Electrical Conductivity}

Across the three loads of PPS, the $\mathrm{pH}$ and electrical conductivity (EC) of biochar generated at temperatures of $350-400{ }^{\circ} \mathrm{C}$ and $450-500{ }^{\circ} \mathrm{C}$ ranged from 7.4 to 7.8 and 0.01 to $0.05 \mathrm{dS} \mathrm{m}^{-1}$, respectively (Table 3). All of the biochar samples had a mildly alkaline $\mathrm{pH}$ (pH 7.4-7.8). However, the loading rate and temperature had no significant effect on biochar $\mathrm{pH}$. The $\mathrm{pH}$ value of the biochar increased with a concomitant increase in temperature range within each load, a characteristic that was found associated with an increase in temperature [26]. Higher $\mathrm{pH}$ of biochar at $450-500{ }^{\circ} \mathrm{C}$ was probably due to a decrease in acid functional groups at higher temperature as indicated by the higher CEC (indicative of carboxyl groups) of lower $\mathrm{pH}$ biochar produced under $350-400{ }^{\circ} \mathrm{C}$. The presence of carbonates, inorganic alkalis and increased ash residue portion due to dihydroxylation of inorganic and organic matrices explains well the high $\mathrm{pH}$ value at $450-500{ }^{\circ} \mathrm{C}$ than at $350-400{ }^{\circ} \mathrm{C}$ [26]. The alkalinity of PPS biochar can be potentially employed as a soil amendment for the amelioration of acidic soils through a liming effect [29]. 
Table 3. Effect of process parameters on chemical properties of biochar produced from PPS.

\begin{tabular}{|c|c|c|c|c|c|c|c|c|c|c|}
\hline \multirow{2}{*}{$\begin{array}{c}\text { Load } \\
\left(k^{-1} \text { kiln }^{-1}\right)\end{array}$} & \multirow{2}{*}{$\begin{array}{c}\text { Reaction } \\
\text { Time } \\
\text { (min.) }\end{array}$} & \multirow{2}{*}{$\begin{array}{c}\text { Temp. } \\
\text { Range } \\
\left({ }^{\circ} \mathrm{C}\right)\end{array}$} & \multirow{2}{*}{$\mathrm{pH}$} & \multirow{2}{*}{$\begin{array}{c}\text { EC } \\
\left(\mathrm{dS} \mathrm{m}^{-1}\right)\end{array}$} & \multirow{2}{*}{$\begin{array}{c}\text { CEC } \\
\left(\mathrm{cmol} \mathrm{kg}^{-1}\right)\end{array}$} & \multicolumn{4}{|c|}{ Total Concentration $\left(\mathrm{g} \mathrm{kg}^{-1}\right)$} & \multirow{2}{*}{$\begin{array}{l}\mathrm{C} / \mathrm{N} \\
\text { Ratio }\end{array}$} \\
\hline & & & & & & $\mathbf{N}$ & $\mathbf{P}$ & $\mathbf{K}$ & C & \\
\hline 8 & 9 & $350-400$ & $7.4 \pm 0.22^{a}$ & $0.01 \pm 0.0^{b}$ & $17.0 \pm 1.0^{\mathrm{c}}$ & $11.1 \pm 0.7^{\mathrm{d}}$ & $3.3 \pm 0.2^{\mathrm{e}}$ & $4.0 \pm 0.6^{a}$ & $665.7 \pm 0.8^{\mathrm{e}}$ & 60.5 \\
\hline 8 & 10 & $450-500$ & $7.4 \pm 0.08^{a}$ & $0.02 \pm 0.01^{\mathrm{ab}}$ & $14.0 \pm 3.0^{c}$ & $13.0 \pm 1.0^{b c}$ & $4.0 \pm 0.2^{\mathrm{de}}$ & $4.0 \pm 0.6^{\mathrm{a}}$ & $666.4 \pm 6.0^{\mathrm{e}}$ & 51.3 \\
\hline 13 & 11 & $350-400$ & $7.5 \pm 0.08^{a}$ & $0.03 \pm 0.01^{\mathrm{ab}}$ & $39.0 \pm 3.0^{\mathrm{a}}$ & $11.0 \pm 0.5^{\mathrm{d}}$ & $5.0 \pm 0.2^{c}$ & $4.1 \pm 0.3^{\mathrm{a}}$ & $719.0 \pm 4.0^{\mathrm{d}}$ & 65.4 \\
\hline 13 & 13 & $450-500$ & $7.7 \pm 0.08^{a}$ & $0.04 \pm 0.01^{\mathrm{ab}}$ & $33.0 \pm 0.9^{b}$ & $14.0 \pm 1.0^{\mathrm{b}}$ & $6.0 \pm 0.2^{b}$ & $4.0 \pm 0.3^{\mathrm{a}}$ & $730.0 \pm 4.0^{c}$ & 52.1 \\
\hline 18 & 15 & $350-400$ & $7.6 \pm 0.22^{a}$ & $0.05 \pm 0.01^{\mathrm{a}}$ & $43.0 \pm 1.0^{\mathrm{a}}$ & $11.3 \pm 0.3^{\mathrm{cd}}$ & $3.8 \pm 0.3^{\text {de }}$ & $4.1 \pm 0.2^{\mathrm{a}}$ & $740.0 \pm 2.0^{b}$ & 65.8 \\
\hline 18 & 16 & $450-500$ & $7.8 \pm 0.08^{a}$ & $0.05 \pm 0.01^{\mathrm{a}}$ & $40.0 \pm 1.0^{\mathrm{a}}$ & $17.0 \pm 0.6^{\mathrm{a}}$ & $8.0 \pm 0.3^{\mathrm{a}}$ & $4.0 \pm 0.6^{\mathrm{a}}$ & $756.5 \pm 1.0^{\mathrm{a}}$ & 44.5 \\
\hline
\end{tabular}

Value is the mean \pm standard deviation; mean values followed by different letters within the same column are significantly different ( $p<0.05 ; n=4$; ANOVA; Tukey's HSD test).

All of the biochars studied were non-saline $\left(0-2.0 \mathrm{dS} \mathrm{m}^{-1}\right)$ in nature, with electrical conductivity values ranging from 0.01 to $0.05 \mathrm{dS} \mathrm{m}^{-1}$. Contrary to $\mathrm{pH}$, biochar had lower electrical conductivity values $\left(0.01-0.05 \mathrm{dS} \mathrm{m}^{-1}\right)$. The highest electrical conductivity values $\left(0.05 \mathrm{dS} \mathrm{m}^{-1}\right)$ were observed for biochar produced at $450-500{ }^{\circ} \mathrm{C}\left(\right.$ at $\left.18.0 \mathrm{~kg} \mathrm{kiln}^{-1}\right)$. The rise in biochar EC values could be attributed to a rise in temperature. The findings are similar to those of Kloss et al., [27]. Based on the findings, it is possible that biochar produced in this study, due to its lower EC values, will not have an unfavourable influence on soil EC when used as a soil amendment. As the EC value of the biochar change influence the nutrient availability in the soil, the quantity and frequency of its application should be carefully determined for various soil types.

\subsubsection{Cation Exchange Capacity}

Cation exchange capacity (CEC) of biochar is indicative of the capacity of biochar to retain key nutrient cations in a plant-available form [32]. A kiln temperature increase from $350-400{ }^{\circ} \mathrm{C}$ to $450-500{ }^{\circ} \mathrm{C}$ induced a significant reduction in the CEC of biochar from 43.0 to $14.0 \mathrm{cmol} \mathrm{kg}^{-1}$ across the loads (Table 3). This finding agrees with those of Gaskin et al., [23] and Singh et al., [62]. A decrease in surface acidic functional groups with an increase in temperature range $[63,64]$ might have contributed to the lower CEC values associated with the biochar in the present study. Significantly higher CEC $\left(43.0 \mathrm{cmol} \mathrm{kg}^{-1}\right)$ in biochar was observed with $18.0 \mathrm{~kg}$ load kiln ${ }^{-1}$ at $350-400{ }^{\circ} \mathrm{C}$, which supports the relationship between functional groups and biochar CEC [29,32]. The presence of negatively charged functional groups on the biochar surface gives biochar its ability to attract, retain and exchange basic cations [28]. Low CEC values of the biochar produced at the higher temperature of $450-500{ }^{\circ} \mathrm{C}$ do not seem to have strong nutrient retention potential if applied fresh in soil.

\subsubsection{Total Carbon (C), Nitrogen (N), Phosphorous (P) and Potassium (K)}

The total C, N and P composition of biochar was strongly influenced by the PPS composition and kiln temperature (Table 3). Significantly higher total C $\left(756.5 \mathrm{~g} \mathrm{~kg}^{-1}\right)$, total $\mathrm{N}\left(17.0 \mathrm{~g} \mathrm{~kg}^{-1}\right)$ and total $\mathrm{P}\left(8.0 \mathrm{~g} \mathrm{~kg}^{-1}\right)$ concentration in the biochar was recorded at a load of $18 \mathrm{~kg} \mathrm{kiln}^{-1}\left(450-500^{\circ} \mathrm{C}\right)$. The effect of kiln temperature on the total $\mathrm{K}$ concentration of biochar was non-significant.

Total C content in biochar increased with an increase in the kiln temperature [22]. Total C content changed in the range of 665.7 to $666.4 \%, 719.0$ to $730.0 \%, 740.0 \%$ to $756.5 \%$ with an increase in the kiln temperature from $350-400$ to $450-500{ }^{\circ} \mathrm{C}$, respectively, in each of 8.0, 13.0 and $18.0 \mathrm{~kg}$ load kiln ${ }^{-1}$. PPS biochar had a total C enrichment of 1.6 times that of PPS [29] and could be an effective source of soil carbon sequestration. Increasing temperature, enrichment through dehydration, condensation, polymerization and aromatization effectively favoured the total C content in PPS biochar [22,29].

Similarly, with an increase in temperature at different loading rates, the total $\mathrm{N}$ content in biochar was 1.18-1.82 times higher than that of the PPS. Aromatization [23] is largely responsible for the incorporation of $\mathrm{N}$ into heterocyclic structures such as pyridines or pyrrols [24]. This could explain the enrichment of total $\mathrm{N}$ in PPS biochar relative to the original feedstock [29] with the increase in kiln temperature. The biochar $\mathrm{C} / \mathrm{N}$ ratios ranged between 44.5 and 65.8 and were found to decrease with increasing temperature [31]. Gener- 
ally, higher $\mathrm{C} / \mathrm{N}$ ratios are reported to result in inorganic $\mathrm{N}$ immobilization by microbes which induce $\mathrm{N}$ unavailability for plants [28]. Even though our results suggest wider $\mathrm{C} / \mathrm{N}$ ratios, the recalcitrance nature of biochar may resist microbial decay to an extent suggesting that biochar as a soil amendment has little influence on soil $\mathrm{N}$ immobilization [65].

The results of the present study showed that similarly to total N, the total concentrations of essential nutrients (total $\mathrm{K}$ and P) in biochar were higher compared to PPS, suggesting that the principal chemical components were concentrated in the biochar during the slow pyrolysis of stalks [24]. The total concentrations of K and P in biochar were 2.8 and 1.7 times higher than those in PPS which could explain the nutrient enrichment during conversion. These results are consistent with an earlier study reported for castor stalk biochar [30] which found that the nutrient concentrations of stalk and kiln temperature can strongly influence biochar contents. The $\mathrm{K}$ and $\mathrm{P}$ need a charring temperature above $760^{\circ} \mathrm{C}$ and $800^{\circ} \mathrm{C}$, respectively, to vaporize [66,67] during slow pyrolysis whereas the higher limit adopted in the present study was $450-500^{\circ} \mathrm{C}$. Therefore, initial nutrient concentrations of the stalk and reduced volatilization losses might have contributed to the effective retention of nutrients in biochar [24].

\subsubsection{Recovery of Total Carbon and Nitrogen}

The amount of total carbon $(\mathrm{C})$ and nitrogen $(\mathrm{N})$ recovered in the PPS biochar varied depending upon the respective ash content and temperature range (Table 4). The recovered total $\mathrm{C}$ and $\mathrm{N}$ in the biochar reduced with the increase in temperature from $350-400{ }^{\circ} \mathrm{C}$ to $450-500{ }^{\circ} \mathrm{C}$ in all three loads. The recovered total $\mathrm{C}$ and $\mathrm{N}$ ranged from 58.1 to $21.4 \%$ and 52.5 to $16.7 \%$ in the biochar produced from PPS at a temperature of $350-400{ }^{\circ} \mathrm{C}$ and $450-500{ }^{\circ} \mathrm{C}$, respectively. A significantly higher amount of total $\mathrm{C}(58.1 \%)$ and total $\mathrm{N}$ (52.5\%) was recovered in the biochar produced with $18 \mathrm{~kg}$ load $\mathrm{kiln}^{-1}$ at $350-400{ }^{\circ} \mathrm{C}$ and $450-500{ }^{\circ} \mathrm{C}$, respectively. At different temperatures within each load, the recovered total $\mathrm{C}$ in biochar was inversely proportional to the ash content of the corresponding biochars. Significant changes in the amount of total $\mathrm{C}$ recovered with an increase in the production temperature range might have been related to the original feedstock concentrations of ash, lignin, cellulose, and hemicellulose and the pyrolysis temperature [60]. Present results on the amount of total $\mathrm{C}$ recovered in biochar might have been influenced due to the volatilization of carbon elements bonded with volatile chemicals constituents compared to less volatile elements that concentrated during carbonization [27]. However, the recovered total $\mathrm{N}$ in the biochar was inversely proportional to an increase in the temperature range within each load. Novak et al., [24] ascribed the variation in the recovery of total $\mathrm{N}$ to condensation of $\mathrm{N}$-containing structures in the biochar into recalcitrant heterocyclic $\mathrm{N}$ rather than the more bioavailable amine $\mathrm{N}$. Furthermore, $\mathrm{N}$ volatilization in gaseous form at low temperatures could have resulted in lower total $\mathrm{N}$ recovery in the current study [25].

Table 4. Changes in total carbon (C) and nitrogen (N) levels during conversion of PPS to biochar.

\begin{tabular}{|c|c|c|c|c|c|c|c|c|c|}
\hline $\begin{array}{c}\text { Load } \\
\left(\mathrm{kg}^{-}\right. \\
\left.\text {kiln }^{-1}\right)\end{array}$ & $\begin{array}{l}\text { Reaction } \\
\text { Time } \\
\text { (min.) }\end{array}$ & $\begin{array}{l}\text { Temp. } \\
\text { Range } \\
\left({ }^{\circ} \mathrm{C}\right)\end{array}$ & $\begin{array}{l}\text { Biochar } \\
\text { Yield } \\
\text { (kg) }\end{array}$ & $\begin{array}{c}\text { Total C in } \\
\text { PPS } \\
(\mathrm{kg})\end{array}$ & $\begin{array}{c}\text { Total C } \\
\text { in Biochar } \\
(\mathbf{k g})\end{array}$ & $\begin{array}{c}\text { C Recovery } \\
\text { in Biochar } \\
(\%)\end{array}$ & $\begin{array}{c}\text { Total N } \\
\text { in PPS } \\
(\mathrm{kg})\end{array}$ & $\begin{array}{c}\text { Total N } \\
\text { in Biochar } \\
(\mathbf{k g})\end{array}$ & $\begin{array}{c}\text { N Recovery } \\
\text { in Biochar } \\
(\%)\end{array}$ \\
\hline 8 & 9 & $350-400$ & 1.7 & 3.7 & 1.1 & $30.8 \pm 0.04^{\mathrm{a}}$ & 0.10 & 0.02 & $20.7 \pm 1.3^{a}$ \\
\hline 8 & 10 & $450-500$ & 1.5 & 3.7 & 1.0 & $26.8 \pm 0.23^{b}$ & 0.10 & 0.02 & $21.2 \pm 1.6^{b}$ \\
\hline 13 & 11 & $350-400$ & 2.8 & 6.0 & 2.0 & $33.8 \pm 0.20^{c}$ & 0.10 & 0.03 & $21.0 \pm 1.0^{\mathrm{c}}$ \\
\hline 13 & 13 & $450-500$ & 1.8 & 6.0 & 1.3 & $21.4 \pm 0.11^{\mathrm{d}}$ & 0.10 & 0.02 & $16.7 \pm 1.1^{c}$ \\
\hline 18 & 15 & $350-400$ & 6.5 & 8.3 & 4.8 & $58.1 \pm 0.12^{\mathrm{e}}$ & 0.20 & 0.07 & $36.0 \pm 0.9^{c}$ \\
\hline 18 & 16 & $450-500$ & 6.3 & 8.3 & 4.8 & $57.6 \pm 0.10^{\mathrm{f}}$ & 0.20 & 0.11 & $52.5 \pm 1.8^{\mathrm{d}}$ \\
\hline
\end{tabular}

PPS: pigeon pea stalk; ${ }^{\#}$ value is the mean \pm standard deviation; mean values followed by different letters within the same column are significantly different ( $p<0.05 ; n=4$; ANOVA; Tukey's HSD test). 


\subsubsection{Biochar Stability}

The VM, FC and Ash composition of the biochar was used to calculate the $\mathrm{O} / \mathrm{C}$ and $\mathrm{H} / \mathrm{C}$ atomic ratios by using Equations (1) and (2) which is likely to be an indicative measure of the degree of biochar stability in the soil.

The data in Table 5 showed that the ratios in all biochars declined steadily as the kiln temperature increased, indicating the loss of degradable polar contents $[9,39,42]$ with a higher degree of condensation and aromatisation reactions with increasing temperature [38]. The $\mathrm{O} / \mathrm{C}$ and $\mathrm{H} / \mathrm{C}$ atomic ratios of PPS biochar ranged between $0.07-0.15$ and $0.35-0.50$, respectively. $\mathrm{O} / \mathrm{C}$ and $\mathrm{H} / \mathrm{C}$ atomic ratios decreased with the increase in temperature from $350-400{ }^{\circ} \mathrm{C}$ to $450-500{ }^{\circ} \mathrm{C}$ in all three loads suggesting that the lower the $\mathrm{O} / \mathrm{C}$ and $\mathrm{H} / \mathrm{C}$ atomic ratios, the higher degree of aromaticity and stability with increasing kiln temperature [36]. The reduction in $\mathrm{H} / \mathrm{C}$ atomic ratio suggests higher structural stability in PPS biochars due to increased aromatisation [41]. The reduction in ratio can be attributed to the removal of hydrogen through dehydration and dehydrogenation reactions and the cleavage and cracking of weak hydrogen bonds during conversion within the biochar, similar to the observations of Qian et al., [68]. Whereas the decreased $\mathrm{O} / \mathrm{C}$ atomic ratio implies that the higher degree of carbonization occurred by removal of oxygen through dehydration and decarboxylation reactions during conversion [40,41]. These characteristics give biochar long-term chemical stability against microbial degradation [36], allowing it to persist in soil for hundreds of years [43]. The results of previous research suggested that the aromaticity of biochar formed at higher pyrolysis temperatures was stronger and had lower $\mathrm{H} / \mathrm{C}$ and $\mathrm{O} / \mathrm{C}$ atomic ratios than biochar prepared at lower temperatures [10]. The data proved that pyrolysis studies conducted in this study were successful in converting PPS into biochar with decreasing $\mathrm{H} / \mathrm{C}$ and $\mathrm{O} / \mathrm{C}$ atomic ratios with increasing temperature in all three loads, indicative of improved fuel properties comparable to lignite, sub-bituminous bituminous coal with higher heating values.

Table 5. Estimates of $\mathrm{H}, \mathrm{O}, \mathrm{O} / \mathrm{C}$ and $\mathrm{H} / \mathrm{C}$ atomic ratios, total potential carbon and $\mathrm{CO}_{2}$ reduction potential of PPS biochar.

\begin{tabular}{|c|c|c|c|c|c|c|}
\hline \multirow{3}{*}{$\begin{array}{c}\text { Parameters } \\
\text { Load }\left(\mathrm{kg} \mathrm{kiln}^{-1}\right) \\
\text { Reaction time (min.) }\end{array}$} & \multicolumn{6}{|c|}{ Biochar Production Conditions } \\
\hline & \multicolumn{2}{|c|}{8} & \multicolumn{2}{|c|}{13} & \multicolumn{2}{|c|}{18} \\
\hline & 9 & 10 & 11 & 13 & 15 & 16 \\
\hline Temp. range $\left({ }^{\circ} \mathrm{C}\right)$ & $350-400$ & $450-500$ & $350-400$ & $450-500$ & $350-400$ & $450-500$ \\
\hline \multicolumn{7}{|c|}{ Biochar stability } \\
\hline $\mathrm{H}$ & 2.38 & 1.73 & 1.68 & 1.42 & 1.86 & 1.76 \\
\hline $\mathrm{O}$ & 10.33 & 5.50 & 5.06 & 3.12 & 6.29 & 5.47 \\
\hline $\mathrm{O} / \mathrm{C}$ atomic ratio & 0.15 & 0.11 & 0.10 & 0.08 & 0.10 & 0.07 \\
\hline $\mathrm{H} / \mathrm{C}$ atomic ratio & 0.50 & 0.40 & 0.39 & 0.35 & 0.38 & 0.33 \\
\hline Mean resident time (years) & 903.60 & 1231.66 & 1274.78 & 1462.75 & 1333.41 & 1553.58 \\
\hline $\mathrm{BC}_{+100}(\%)$ & 74.08 & 80.05 & 80.72 & 83.36 & 81.58 & 84.52 \\
\hline \multicolumn{7}{|c|}{$\mathrm{CO}_{2}$ reduction potential } \\
\hline Total potential carbon $\left(\mathrm{g} \mathrm{kg}^{-1}\right)$ & 87.56 & 79.58 & 94.37 & 62.93 & 187.07 & 228.66 \\
\hline $\mathrm{CO}_{2}$ reduction potential $\left(\mathrm{CO}_{2}\right.$ eq $\left.\mathrm{kg}^{-1}\right)$ & 25.69 & 23.34 & 27.68 & 18.46 & 54.87 & 67.07 \\
\hline
\end{tabular}

In a comprehensive review by Lehmann et al., [37], two equations, Equations (3) and (4), were suggested to estimate MRT (years)and the mass fraction of carbon that would remain after 100 years $\left(\mathrm{BC}_{+100}\right)$. With an increase in kiln temperature from $350-400{ }^{\circ} \mathrm{C}$ to $450-500{ }^{\circ} \mathrm{C}$ in all three loads, the MRT and the mass fraction of carbon that would remain after 100 years (Table 5) increased. Values of MRT and $\left(\mathrm{BC}_{+100}\right)$ ranged from 903.6 to 1553.58 years. and 74.0 to $84.5 \%$, respectively. The estimated MRT and the mass fraction of carbon that would remain after 100 years were greater than 1000 years and $80 \%$, respectively, for biochar with a $\mathrm{H} / \mathrm{C}$ ratio of 0.33 to 0.40 [25,37]. As per IBI Guidelines [69] and European biochar certificate [70], biochar with $\mathrm{H} / \mathrm{C}<0.7$ and $\mathrm{O} / \mathrm{C}<0.4$ will be effective 
in sequestering carbon when incorporated in the soil. Hence, the biochar developed in this study could be used in carbon-deficient soils with the added benefit of long-term carbon storage.

\subsection{7. $\mathrm{CO}_{2}$ Reduction Potential}

The amount of TPC (Equation (5)) and $\mathrm{CO}_{2}$ reduction potential (Equation (6)) of the biochar produced at varying production conditions decreased with an increase in temperature under 8 and $13 \mathrm{~kg}$ load $\mathrm{kiln}^{-1}$ (Table 5). This is due to the reduction in biochar yield as the kiln temperature increases [46]. Even though the reduction in biochar yield was observed with an increase in temperature from $350-400{ }^{\circ} \mathrm{C}$ to $450-500{ }^{\circ} \mathrm{C}$, biochar produced from $18 \mathrm{~kg}$ load $\mathrm{kiln}^{-1}$ recorded the highest TPC (228.66 $\left.\mathrm{g} \mathrm{kg}^{-1}\right)$ and $\mathrm{CO}_{2}$ reduction potential $\left(67.07 \mathrm{CO}_{2} \mathrm{eq} \mathrm{kg}^{-1}\right)$. The conversion of PPS using this protocol resulted in a more stable form of carbon (biochar) that can withstand microbial decomposition and therefore can store atmospheric $\mathrm{CO}_{2}$ in soil. This unstable carbon in crop waste would have otherwise been rapidly mineralized to carbon dioxide if either left to decompose naturally or burned in-situ. The findings also indicate that PPS biochar produced at $450-500{ }^{\circ} \mathrm{C}$ under $18 \mathrm{~kg}$ load kiln ${ }^{-1}$ with the highest organic carbon $\left(756.5 \mathrm{~g} \mathrm{~kg}^{-1}\right)$ could be exploited as an agent for long term carbon storage in soil as a climate change mitigation option. This could be due to the large quantity of atmospheric carbon dioxide (to the tune of $67.07 \mathrm{CO}_{2}$ eq $\mathrm{kg}^{-1}$ ) converted into a more stable form of carbon that is resistant to degradation and persists in soil for a longer time [71].

Production data collected by the Ministry of Agriculture \& Farmers Welfare, Government of India, during 2016-2017 indicated that India produced $18.53 \mathrm{Mt} \mathrm{yr}^{-1}$ of PPS from a gross cropped area of 5.34 $\mathrm{M}$ ha (residue crop ratio: $3.8 \mathrm{t} \mathrm{t}^{-1}$ and an average yield of the pigeon pea crop: $0.913 \mathrm{t} \mathrm{ha}^{-1}$ ) [19]. Based on the present results of $35 \%$ biochar yield at $450-500{ }^{\circ} \mathrm{C}$ with $65 \% \mathrm{FC}$ content in PP stalk biochar, the estimated biochar production potential $\left(\mathrm{Mt} \mathrm{yr}^{-1}\right)$, TPC $\left(\mathrm{Mt} \mathrm{yr}^{-1}\right)$ and $\mathrm{CO}_{2}$ reduction potential $\left(\mathrm{Mt} \mathrm{C} \mathrm{CO}_{2} \mathrm{eq} \mathrm{yr}^{-1}\right)$ of biochar from PPS in India is 6.48, 4.23 and 12.42, respectively. Application of PPS biochar in agricultural soils can sequester about 3.39 $\mathrm{Mt} \mathrm{yr}^{-1}$ of carbon, making it a carbon sequestering process.

\subsubsection{Energy Related Properties}

Table 6 presents the estimated values of energy-related properties of biochar produced at different conditions from PPS including fuel ratio (Fr), energy retention efficiency, energy densification (Ed), HHV, HHV improvement (HHVi), FC densification (FCd), FC recovery efficiency (FCre). These parameters are considered the basis for evaluating the quality of biochar as an energy source. The energy properties of biochar improved via chemical dehydration and decarboxylation reactions that release $\mathrm{H}_{2} \mathrm{O}$ and $\mathrm{CO}_{2}$ [72]. Along with a loss in weight, these reactions cause a decrease in the volatile matter and an increase in carbon content in the biochar as compared to the raw PPS [48]. These results suggest that longer reaction times and higher temperature ranges may provide greater potential energy recovery in PPS biochar. The FC content and FC densification of the PPS biochar increased with reaction times and temperature range (Tables 1 and 6). Increases in FC densification with temperature have also been observed in other studies [47]. FC densification has important energy-related implications [47,73].

The energetic retention efficiency is an important parameter to assess the effect of production conditions of biochar as an alternative solid fuel. The energetic retention efficiency is a measure of the fraction of PPS energy retained within the biochar, was $\mathrm{s}$ greater at $350-400{ }^{\circ} \mathrm{C}$ and $450-500{ }^{\circ} \mathrm{C}$ (at $18.0 \mathrm{~kg} \mathrm{kiln}^{-1}$ ) than that at other loading rates, as biochar yield was higher at that temperature. The energetic retention efficiency at 350-400 ${ }^{\circ} \mathrm{C}$ and $450-500{ }^{\circ} \mathrm{C}$ (at 8.0 and $13.0 \mathrm{~kg} \mathrm{kiln}^{-1}$ ) decreased slightly with reaction times because of the decreases in biochar yield. These results suggest that the optimum temperature for the production of energy-rich biochar is approximately $450-500{ }^{\circ} \mathrm{C}$. 
Table 6. Estimates of fuel properties of PPS biochar.

\begin{tabular}{|c|c|c|c|c|c|c|}
\hline \multirow{4}{*}{$\begin{array}{c}\text { Parameters } \\
\text { Load }\left(\mathrm{kgkiln}{ }^{-1}\right) \\
\text { Reaction time }(\mathrm{min} .) \\
\text { Temp. range }\left({ }^{\circ} \mathrm{C}\right)\end{array}$} & \multicolumn{6}{|c|}{ Biochar Production Conditions } \\
\hline & \multicolumn{2}{|c|}{8} & \multicolumn{2}{|c|}{13} & \multicolumn{2}{|c|}{18} \\
\hline & 9 & 10 & 11 & 13 & 15 & 16 \\
\hline & $350-400$ & $450-500$ & $350-400$ & $450-500$ & $350-400$ & $450-500$ \\
\hline \multicolumn{7}{|c|}{ Fuel Properties } \\
\hline Fuel ratio & 1.6 & 2.6 & 2.8 & 3.96 & 3.08 & 4.88 \\
\hline Energetic retention efficiency $(\%)$ & 23.6 & 19.6 & 23.0 & 14.7 & 45.2 & 53.0 \\
\hline Energy densification & 1.1 & 1.06 & 1.1 & 1.09 & 1.25 & 1.51 \\
\hline $\mathrm{HHV}\left(\mathrm{MJ} \mathrm{kg}^{-1}\right)$ & 18.3 & 17.53 & 17.6 & 18.02 & 20.74 & 25.01 \\
\hline HHV improvement & 0.1 & 0.06 & 0.1 & 0.09 & 0.25 & 0.51 \\
\hline FC densification & 2.42 & 2.53 & 2.58 & 2.75 & 3.05 & 3.84 \\
\hline FC recovery efficiency (\%) & 51.51 & 46.81 & 55.51 & 37.02 & 110.04 & 134.50 \\
\hline
\end{tabular}

The energy densification was similar at $350-400{ }^{\circ} \mathrm{C}$ and $450-500{ }^{\circ} \mathrm{C}$ (at 8.0 and $13.0 \mathrm{~kg} \mathrm{kiln}^{-1}$ ). Energy densification increased with reaction time and was slightly higher at $350-400{ }^{\circ} \mathrm{C}$ and $450-500{ }^{\circ} \mathrm{C}$ (at $18.0 \mathrm{~kg} \mathrm{kiln}^{-1}$ ). Energy densification in biochar has been reported for a variety of crop residues $[47,74]$.

The HHV, which describes the energy content of biochar, is one of the most essential metrics for determining its potential fuel value. The higher heating value of any fuel is defined as "the energy released per unit mass or per unit volume of the fuel after complete combustion, including all the released energy during combustion in addition to the energy carried away with water vaporization [75]. The HHV of biochar were ranged from 18.3 to $25.01 \mathrm{MJ} \mathrm{kg}^{-1}$ (Table 6). The HHV for each biochar sample increased with higher temperature $\left(350-400{ }^{\circ} \mathrm{C}\right.$ to $450-500{ }^{\circ} \mathrm{C}$ at 13.0 and $18.0 \mathrm{~kg} \mathrm{kiln}^{-1}$ ) with a larger increase occurring at $350-400{ }^{\circ} \mathrm{C}$ to $450-500{ }^{\circ} \mathrm{C}$ at $18.0 \mathrm{~kg} \mathrm{kiln}^{-1}$. Differences in HHV of the biochar are attributable to relative ash contents [50]. The HHV of PPS biochar $\left(20.74 \mathrm{MJ} \mathrm{kg}^{-1}\right)$ at $350-400{ }^{\circ} \mathrm{C}$ (at $18.0 \mathrm{~kg} \mathrm{kiln}^{-1}$ ) was slightly lower than that of lignite $\left(20.89 \mathrm{MJ} \mathrm{kg}^{-1}\right)$ [76], whereas the HHV of biochar $\left(25.01 \mathrm{MJ} \mathrm{kg}^{-1}\right.$ ) at $450-500{ }^{\circ} \mathrm{C}\left(\right.$ at $18.0 \mathrm{~kg} \mathrm{kiln}^{-1}$ ) was higher than that of sub-bituminous coal (24.30 $\left.\mathrm{MJ} \mathrm{kg}^{-1}\right)$ [5] and slightly lower than that of bituminous coal (25.84 MJ kg-1) [4] that showed their high energy potentials. The evaporation of low-energy elements like oxygen, hydrogen, and nitrogen to leave high-energy carbon resulted in an increase in HHV [49]. The higher FC (65.3\%), energy density (1.51), energetic retention efficiency $(53 \%)$, fuel ratio (4.88) and $\mathrm{HHV}\left(25.01 \mathrm{MJ} \mathrm{kg}^{-1}\right)$, as well as the lower $\mathrm{H} / \mathrm{C}$ and $\mathrm{O} / \mathrm{C}$ ratios indicate that the biochar produced at $450-500{ }^{\circ} \mathrm{C}\left(\right.$ at $18.0 \mathrm{~kg} \mathrm{kiln}^{-1}$ ) from PPS can be used as an alternative solid fuel [77].

\section{Conclusions}

This study presented the feasibility of producing biochar from PPS under varying production conditions, which could be immensely useful for the efficient management of surplus crop waste. Fixed carbon, ash, total carbon, total N, P and porosity in the PPS biochar increased, whereas the biochar yield, volatile matter, cation exchange capacity and recovered total $\mathrm{C}$ and $\mathrm{N}$ decreased with an increase in the kiln temperature from $350-400{ }^{\circ} \mathrm{C}$ to $450-500{ }^{\circ} \mathrm{C}$. PPS biochar having lower bulk density, higher total $\mathrm{C}$ and recovered $\mathrm{C}$ and $\mathrm{N}$ with low $\mathrm{H} / \mathrm{C}$ and $\mathrm{O} / \mathrm{C}$ atomic ratios could be useful for restoration of degraded poor agricultural soils through enhanced carbon sequestration. Biochar produced from PPS exhibited good agronomic properties and fulfilled key quality criteria of $\mathrm{H} / \mathrm{C}<0.7$ and $\mathrm{O} / \mathrm{C}<0.4$ for soil carbon sequestration, as described by the European Biochar Certificate (EBC) and the International Biochar Initiative (IBI). Maximum TPC (228.66 g kg-1) and $\mathrm{CO} 2$ reduction potential $(67.07 \mathrm{CO} 2 \mathrm{eq} \mathrm{kg}-1)$ were observed in the PPS biochar produced at $450-500{ }^{\circ} \mathrm{C}$ and $18 \mathrm{~kg}$ load kiln-1. The estimated mean residence time (MRT) and the mass fraction of carbon that would remain after 100 years were greater than 1000 years and $80 \%$, respectively, for PPS biochar with a $\mathrm{H} / \mathrm{C}$ atomic ratio from 0.33 to 0.40 . This 
study provides information on optimized procedures for biochar production from PPS with properties suitable for long term storage of carbon in agricultural soil, viz., higher aromatic character, high carbon concentration, low $\mathrm{H} / \mathrm{C}$ atomic ratio. The biochar also had higher HHVs and fixed carbon contents, which can be considered as a suitable alternative solid fuel for energy applications.

Author Contributions: Conceptualization, G.V.; methodology, G.V. and K.A.G.; formal analysis, G.V. and K.A.G.; investigation, G.V. and B.S.R.; resources, B.S.R. and M.P.; data curation, K.S.R. and C.S.; writing-G.V.; writing-review and editing, G.V., K.A.G. and V.V.K.; supervision, K.S.R. and K.A.G.; project administration, V.K.S. All authors have read and agreed to the published version of the manuscript.

Funding: This work was financially supported by grants from the Indian Council of Agricultural Research (ICAR), New Delhi in the form of the National Innovations in Climate Resilient Agriculture (NICRA) Project (Grant number:2-2(201)/17-18/NICRA).

Institutional Review Board Statement: Not applicable.

Informed Consent Statement: Not applicable.

Data Availability Statement: The data is available on request from the corresponding author for reasonable reasons.

Conflicts of Interest: The authors declare no conflict of interest.

\section{References}

1. Gul, S.; Whalen, J.K.; Thomas, B.W.; Sachdeva, V.; Deng, H. Physico-chemical properties and microbial responses in biocharamended soils: Mechanisms and future directions. Agric. Ecosyst. Environ. 2015, 206, 46-59.

2. Masto, R.E.; Kumar, S.; Rout, T.K.; Sarkar, P.; George, J.; Ram, L.C. Biochar from water hyacinth (Eichornia crassipes) and its impact on soil biological activity. Catena 2013, 111, 64-71. [CrossRef]

3. Sohi, S.; Krull, E.; Capel, E.L.; Bol, R. A review of biochar and its use and function in soil. Adv. Agron. 2010, 105, 47-82.

4. Geng, C.; Li, S.; Yue, C.; Ma, Y. Pyrolysis characteristics of bituminous coal. J. Energy Inst. 2015, 89, 725-730. [CrossRef]

5. Valde’s, C.F.; Chejne, F.; Marrugo, G.; Macias, R.J.; Go’mez, C.A.; Montoya, J.I.; Londoño, C.A.; Cruz, J.D.L.; Arenas, E. Cogasification of subbituminous coal with palm kernel shell in fluidized bed coupled to a ceramic industry process. Appl. Therm. Eng. 2016, 107, 1201-1209. [CrossRef]

6. Ajayi, A.E.; Horn, R. Modification of chemical andhydro physical properties of two texturally differentiated soils due to varying magnitudes of added biochar. Soil Tillage Res. 2016, 164, 34-44. [CrossRef]

7. Laghari, M.; Hu, Z.; Mirjat, M.S.; Xiao, B.; Tagar, A.A.; Hu, M. Fast pyrolysis biochar from sawdust improves the quality of desert soils and enhances plant growth. J. Sci. Food Agric. 2016, 96, 199-206.

8. Phanphanich, M.; Sudhagar Mani, S. Impact of torrefaction on the grindability and fuel characteristics of forest biomass. Bioresour. Technol. 2011, 102, 1246-1253. [CrossRef] [PubMed]

9. Keiluweit, M.; Nico, P.S.; Johnson, M.G.; Kleber, M. Dynamic molecular structure of plant biomass-derived black carbon (biochar). Environ. Sci. Technol. 2010, 44, 1247-1253. [CrossRef] [PubMed]

10. Wei, S.; Zhu, M.; Song, J.; Peng, P.A. Comprehensive characterization of biochars produced from three major crop straws of China. Bioresources 2017, 12, 3316-3330. [CrossRef]

11. Xu, T.; Lou, L.; Luo, L.; Cao, R.; Duan, D.; Chen, Y. Effect of bamboo biochar on pentachlorophenol leachability and bioavailability in agricultural soil. Sci. Total Environ. 2012, 414, 727-731. [PubMed]

12. Prabha, B.; Pugalendhi, S.; Subramanian, P. Design and development of semi-indirect non-electric pyrolytic reactor for biochar production from farm waste. Indian J. Agric. Sci. 2015, 85, 585-591.

13. Purakayastha, T.J.; Kumari, S.; Pathak, H. Characterization, stability, and microbial effects of four biochars produced from crop residues. Geoderma 2015, 239-240, 293-303. [CrossRef]

14. Jothiprakash, G.; Palaniappan, V. Development and optimization of pyrolysis unit for producing charcoal. Int. J. Agric. Environ. Biotechnol. 2014, 7, 863-868. [CrossRef]

15. Munongo, M.E.; Nkeng, G.E.; Njukeng, J.N. Production and characterization of compost manure and biochar from cocoa pod husks. Int. J. Adv. Scient. Res. Manag. 2017, 2, 26-31.

16. Ministry of New and Renewable Energy Resources. National Biomass Resource. Atlas; 2009. Available online: https:// biomasspower.gov.in/biomass-info-asa-fuel-resources.php (accessed on 12 January 2020).

17. Kaur, A. Crop residue in Punjab agriculture- Status and constraints. J. Krishi Vigyan 2017, 5, 22-26. [CrossRef]

18. IARI. Crop Residues Management with Conservation Agriculture: Potential, Constraints and Policy Needs; Indian Agricultural Research Institute: New Delhi, India, 2012; p. 32. 
19. Government of India. Agricultural Statistics at a Glance 2018. Directorate of Economics and Statistics, Ministry of Agriculture and Farmers Welfare, Department of Agriculture, Cooperation and Farmers Welfare, Government of India. 2019. Available online: https:/ / eands.dacnet.nic.in/PDF/Agricultural\%20Statistics\%20at\%20a\%20Glance\%202018.pdf (accessed on 1 February 2020).

20. Venkatesh, G.; Gopinath, K.A.; Reddy, K.S.; Reddy, B.S.; Prasad, J.V.N.S.; Rao, G.R.; Pratibha, G.; Srinivasarao, C.; Chary, G.R.; Prabhakar, M.; et al. Biochar Production and its Use in Rainfed Agriculture: Experiences from CRIDA; CRIDA-NICRA Research Bulletin 02/2018; ICAR_Central Research Institute for Dryland Agriculture: Hyderabad, India, 2018; p. 50.

21. Uzoma, K.C.; Inoue, M.; Andry, H.; Fujimaki, H.; Zahoor, A.; Nishihara, E. Effect of cow manure biochar on maize productivity under sandy soil condition. Soil Use Manag. 2011, 27, 205-212.

22. Gonzalez, M.E.; Cea, M.; Sangaletti, N.; Gonzalez, A.; Toro, C.; Diez, M.C.; Moreno, N.; Querol, X.; Navia, R. Biochar derived from agricultural and forestry residual biomass: Characterization and potential application for enzymes immobilization. J. Biobased Mater. Bioenerg. 2013, 7, 724-732. [CrossRef]

23. Gaskin, J.W.; Steiner, C.; Harris, K.; Das, K.C.; Bibens, B. Effect of low temperature pyrolysis conditions on biochar for agricultural use. Tran. Am. Soc. Agric. Biol. Eng. 2008, 51, 2061-2069.

24. Novak, J.M.; Lima, I.; Xing, B.; Gaskin, J.W.; Steiner, C.; Das, K.C.; Ahmedna, M.; Rehrah, D.; Watts, D.W.; Busscher, W.J.; et al. Characterization of designer biochar produced at different temperatures and their effects on a loamy sand. Ann. Environ. Sci. 2009, 3, 195-206.

25. Enders, A.; Hanley, K.; Whitman, T.; Joseph, S.; Lehmann, J. Characterization of biochars to evaluate recalcitrance and agronomic performance. Bioresour. Technol. 2012, 114, 644-653. [PubMed]

26. Hass, A.; Gonzalez, J.M.; Lima, I.M.; Godwin, H.W.; Halvorson, J.J.; Boyer, D.G. Chicken manure biochar as liming and nutrient source for acid Appalachian soil. J. Environ. Qual. 2012, 41, 1096-1106. [PubMed]

27. Kloss, S.; Zehetner, F.; Dellantonio, A.; Hamid, R.; Ottner, F.; Liedtke, V.; Schwanninger, M.; Gerzabek, M.H.; Soja, G. Characterization of slow pyrolysis biochars: Effects of feedstocks and pyrolysis temperature on biochar properties. J. Environ. Qual. 2012, 41, 990-1000. [PubMed]

28. Uras, U.; Carrier, M.; Hardie, A.G.; Knoetze, J.H. Physico-chemical characterization of biochars from vacuum pyrolysis of South African agricultural wastes for application as soil amendments. J. Anal. Appl. Pyrol. 2012, 98, 207-213. [CrossRef]

29. Wu, W.; Yang, M.; Feng, Q.; McGrouther, K.; Wang, H.; Lu, H.; Chen, Y. Chemical characterization of rice straw-derived biochar for soil amendment. Biomass Bioenerg. 2012, 47, 268-276.

30. Venkatesh, G.; Srinivasarao, C.; Venkateswarlu, B.; Gopinath, K.A.; Prasad, J.V.N.S.; Reddy, B.S.; Sasikala, C.; Rao, G.; Babu, P.V.R. Operational process for biochar preparation from castor bean stalk and its characterization for soil application. Indian J. Dryland Agric. Res. Dev. 2013, 28, 21-26.

31. Venkatesh, G.; Venkateswarlu, B.; Gopinath, K.A.; Srinivasrao, C.; Korwar, G.R.; Reddy, B.S.; Prasad, J.V.N.S.; Grover, M.; Raju, B.M.K.; Sasikala, C.; et al. Biochar production technology for conversion of cotton stalk bioresidue into biochar and its characterization for soil amendment qualities. Indian J. Dryland Agric. Res. Dev. 2013, 28, 48-57.

32. Naeem, M.A.; Khalid, M.; Arshad, M.; Ahmad, R. Yield and nutrient composition of biochar produced from different feedstocks at varying pyrolytic temperatures. Pak. J. Agric. Sci. 2014, 51, 75-82.

33. Xiong, S.; Zhang, S.; Wu, Q.; Guo, X.; Dong, A.; Chen, C. Investigation on cotton stalk and bamboo sawdust carbonization for barbecue charcoal preparation. Bioresour. Technol. 2014, 152, 86-92. [PubMed]

34. Anupam, K.; Sharma, A.K.; Lal, P.S.; Dutta, S.; Maity, S. Preparation, characterization and optimization for upgrading Leucaena leucocephala bark to biochar fuel with high energy yielding. Energy 2016, 106, 743-756.

35. Narzari, R.; Bordoloi, N.; Chutia, R.S.; Borkotoki, B.; Gogoi, N.; Bora, A.; Kataki, R. Biochar: An Overview on its Production, Properties and Potential Benefits. In Biology, Biotechnology and Sustainable Development, Research; Choudhury, H., Ed.; India Publications: New Delhi, India, 2015; pp. 13-39.

36. Kookana, R.S.; Sarmah, A.K.; Van Zwieten, L.; Krull, E.; Singh, B. Biochar application to soil: Agronomic and environmental benefits and unintended consequences. Adv. Agron. 2011, 112, 103-143.

37. Lehmann, J.; Abiven, S.; Kleber, M.; Pan, G.; Singh, B.P.; Sohi, S.P.; Zimmerman, A.R. Persistence of biochar in soil. In Biochar for Environmental Management: Science, Technology, and Implementation, 2nd ed.; Lehmann, J., Joseph, S., Eds.; Routledge: New York, NY, USA, 2015; pp. 235-283.

38. Usman, A.R.A.; Abduljabbar, A.; Vithanage, M.; Ok, Y.S.; Ahmad, M.; Ahmad, M.; Elfaki, J.; Abdulazeem, S.S.; Al-Wabel, M.I. Biochar production from date palm waste: Charring temperature induced changes in composition and surface chemistry. J. Anal. Appl. Pyrol. 2015, 115, 392-400.

39. Klasson, K.T. Biochar characterization and a method for estimating biochar quality from proximate analysis results. Biomass Bioenerg. 2017, 96, 50-58.

40. Shen, Y.; Yu, S.; Ge, S.; Chen, X.; Ge, X.; Chen, M. Hydrothermal carbonization of medical wastes and lignocellulosic biomass for solid fuel production from lab-scale to pilot-scale. Energy 2017, 118, 312-323.

41. Kaewtrakulchai, N.; Fuji, M.; Eiad-ua, A. Investigation of parametric effects on fuel characteristics of biochar obtained from agricultural wastes pyrolysis. J. Material. Sci. Appl. Energ. 2018, 7, 333-339.

42. Wei, S.; Zhu, M.; Fan, X.; Song, J.; Peng, P.; Li, K.; Jia, W.; Song, H. Influence of pyrolysis temperature and feedstock on carbon fractions of biochar produced from pyrolysis of rice straw, pine wood, pig manure and sewage sludge. Chemosphere 2019, 218, 624-631. [PubMed] 
43. Wijitkosum, S.; Jiwnok, P. Elemental composition of biochar obtained from agricultural waste for soil amendment and carbon sequestration. Appl. Sci. 2019, 9, 3980. [CrossRef]

44. Allyson, S. Biochar Production for Carbon Sequestration. Bachelor's Thesis, Worcester Polytechnique Institute, Worcester, MA, USA, 2011.

45. Gangil, S.; Wakudkar, H.M. Generation of bio-char from crop residues. Int. J. Emerging Technol. Adv. Eng. 2013, 3, 566-570.

46. Tesfamichael, B.; Gesesse, N.; Jabasingh, S.A. Application of rice husk and maize straw biochar for carbon sequestration and nitrous oxide emission impedement. J. Sci. Ind. Res. 2018, 77, 587-591.

47. Lu, X.; Pellechia, P.J.; Flora, J.R.V.; Berge, N.D. Influence of reaction time and temperature on product formation and characteristics associated with the hydrothermal carbonization of cellulose. Bioresour. Technol. 2013, 138, 180-190. [CrossRef]

48. Kim, D.; Lee, K.; Park, K.Y. Upgrading the characteristics of biochar from cellulose, lignin, and xylan for solid biofuel production from biomass by hydrothermal carbonization. J Ind. Eng. Chem. 2016, 42, 95-100.

49. Yang, W.; Wang, H.; Zhang, M.; Zhu, J.; Zhou, J.; Wu, S. Fuel properties and combustion kinetics of hydrochar prepared by hydrothermal carbonization of bamboo. Bioresour. Technol. 2016, 205, 199-204. [CrossRef] [PubMed]

50. Ronsse, F.; van Hecke, S.; Dickinson, D.; Prins, W. Production and characterization of slow pyrolysis biochar: Influence of feedstock type and pyrolysis conditions. GCB Bioenergy 2013, 5, 104-115.

51. Nakason, K.; Pathomrotsakun, J.; Kraithong, W.; Khemthong, P.; Panyapinyopol, B. Torrefaction of Agricultural Wastes: Influence of Lignocellulosic Types and Treatment Temperature on Fuel Properties of Biochar. Int. Energy J. 2019, 19, $253-266$.

52. Parikh, J.; Channiwala, S.A.; Ghosal, G.K. A correlation for calculating elemental composition from proximate analysis of biomass materials. Fuel 2007, 86, 1710-1719.

53. Tillman, D.; Rossi, A.J.; William, D.K. Wood Combustion: Principles, Processes, and Economics; Academic Press: New York, NY, USA, 1981; p. 280.

54. Lee, Y.; Park, J.; Ryu, C.; Gang, K.S.; Yang, W.; Park, Y.K.; Jung, J.; Hyun, S. Comparison of biochar properties from biomass residues produced by slow pyrolysis at $500{ }^{\circ} \mathrm{C}$. Bioresour. Technol. 2013, 148, 196-201. [PubMed]

55. Antal, M.J.; Gronli, M. The art, science, and technology of charcoal production. Ind. Eng. Chem. Res. 2003, 42, 1619-1640.

56. ASTM. Standard Test Method for Chemical Analysis of Wood Charcoal D 1762-84; American Society for Testing and Material: West Conshohocken, PA, USA, 2013.

57. Baruah, T.C.; Barthakur, H.P. A Text Book of Soil Analysis; Vikas Publishing House Pvt. Ltd.: New Delhi, India, $1997 ;$ p. 234.

58. Miller, R. Nitric-per Chloric Acid Wet Digestion in an Open Vessel. In Hand Book of Reference Methods for Plant Analysis; Kalra, Y.P., Ed.; CRC Press: New York, NY, USA, 1998; pp. 57-61.

59. Streubel, J.D.; Collins, H.P.; Perez, M.G.; Tarara, J.; Granatstein, D.; Kruger, C.E. Influence of contrasting biochar types on five soils at increasing rates of application. Soil Sci. Soc. Am. J. 2011, 75, 1402-1413.

60. Demirbas, A. Effects of temperature and particle size on bio-char yield from pyrolysis of agricultural residues. J. Anal. Appl. Pyrolysis. 2004, 72, 243-248.

61. Downie, A.; Crosky, A.; Munroe, P. Physical Properties of Biochar. In Biochar for Environmental Management: Science, Technology, and Implementation, 1st ed.; Lehmann, J., Joseph, S., Eds.; Earth Scan: London, UK, 2009; pp. 12-13.

62. Singh, B.; Singh, B.P.; Cowie, A.L. Characterization and evaluation of biochars and their application as a soil amendment. Aust. J. Soil. Res. 2010, 48, 516-525.

63. Harvey, O.R.; Herbert, B.E.; Kuo, L.J.; Louchouarn, P. Generalized two- dimensional perturbation correlation infrared spectroscopy reveals mechanisms for the development of surface charge and recalcitrance in plant-derived biochars. Environ. Sci. Technol. 2012, 46, 10641-10650. [CrossRef] [PubMed]

64. Spokas, K. Review of the stability of biochar in soils: Predictability of O:C molar ratios. Carbon Manag. 2010, 1, $289-303$.

65. Kimetu, J.M.; Lehmann, J.; Ngoze, O.S.; Mugendi, N.D.; Kinyangi, M.J.; Riha, S.; Verchot, L.; Recha, W.J.; Pell, N.A. Reversibility of soil productivity decline with organic matter of differing quality along a degradation gradient. Ecosystems 2008, 11, 726-739.

66. Knoepp, J.D.; Debano, L.F.; Neary, D.G. Soil Chemistry; US Department of Agriculture, Forest Service, Rocky Mountain Research Station: Ogden, UT, USA, 2005.

67. Knicker, H. How does fire affect the nature and stability of soil organic nitrogen and carbon? A review. Biogeochemistry 2007, 85, 91-118.

68. Qian, K.; Kumar, A.; Patil, K.; Bellme, D.; Wang, D.; Yuan, W.; Huhnke, R.L. Effects of Biomass Feedstocks and Gasification Conditions on the Physiochemical Properties of Char. Energies 2013, 6, 3972-3986. [CrossRef]

69. IBI Guidelines. Standardized Product Definition and Product Testing Guidelines for Biochar That Is Used in Soil. 2012 Available online: http://www.biocharnternational.org/sites/default/files/Guidelines_for_Biochar_That_Is_Used_in_Soil_Final. pdf (accessed on 11 October 2015).

70. EBC. European Biochar Certificate-Guidelines for a Sustainable Production of Biochar. European Biochar Foundation (EBC): Arbaz, Switzerland, 2012. Available online: http:/ / www.europeanbiochar.org/en/download (accessed on 1 January 2020).

71. Guo, J.; Chen, B. Insights on the molecular mechanism for the recalcitrance of biochar: Interactive effects of carbon and silicon components. Environ. Sci. Technol. 2014, 48, 9103-9112.

72. Libra, J.A.; Ro, K.S.; Kammann, C.; Funke, A.; Berge, N.D.; Neubauer, Y.; Titirici, M.M.; Fuhner, C.; Bens, O.; Jurgen, K.; et al Hydrothermal carbonization of biomass residuals: A comparative review of the chemistry, processes and applications of wet and dry pyrolysis. Biofuels 2011, 2, 89-124. 
73. Channiwala, S.A.; Parikh, P.P. A unified correlation for estimating HHV of solid, liquid and gaseous fuels. Fuel 2002, 81, 1051-1063.

74. Hoekman, S.K.; Broch, A.; Robbins, C. Hydrothermal carbonization (HTC) of lignocellulosic biomass. Energy Fuels 2011, 25, 1802-1810. [CrossRef]

75. Ghugare, S.B.; Tiwary, S.; Elangovan, V.; Tambe, S.S. Prediction of higher heating value of solid biomass fuels using artificial intelligence formalisms. Bioenergy Res. 2013, 7, 681-692.

76. An, Y.; Tahmasebi, A.; Yu, J. Mechanism of synergy effect during microwave co-pyrolysis of biomass and lignite. J. Anal. Appl. Pyrol. 2017, 128, 75-82. [CrossRef]

77. Abdullah, H.; Wu, H. Biochar as a fuel: 1. Properties and grindability of biochars produced from the pyrolysis of mallee wood under slow-heating conditions. Energy Fuels 2009, 23, 4174-4181. 